\title{
Management of Nematodes with Cowpea Cover Crops ${ }^{1}$
}

\author{
K. -H. Wang and R. McSorley ${ }^{2}$
}

\section{Advantages}

Cover crops are crops grown between cash crop cycles, or crops intercropped with cash crops to cover the ground, such as in vegetable fields, orchards, groves, and agricultural sites. If used appropriately, cover crops can improve soil structure and fertility, decrease soil erosion, provide foliage and animal feed, and suppress crop pests such as weeds, insects, nematodes, and other plant pathogens. Residues from cover crops can be incorporated as green manure to supply nutrients and improve fertility for the next crop. Using cover crops can increase on-farm crop diversity, may enhance many beneficial organisms, and possibly even contribute to carbon sequestration. One good example of a cover crop is cowpea, Vigna unguiculata (L.) Walp.

Cowpea is well adapted to cultivation in the tropics and in the southern United States. One advantage of using cowpea as a cover crop (Figure 1) is its ability to associate with nitrogen-fixing bacteria and thus provide nitrogen for itself and the following crop. The effect of cowpea in nematode management is cultivar dependent. Some cowpea cultivars can be damaged by root-knot nematodes, the key nematode pest in many cropping systems in North Central Florida (McSorley and Gallaher, 1991), resulting in severe root galling (Figure 2). When nematodes build up on cowpea or other cover crops, they can cause damage and yield loss to the next crop planted, which could be a valuable cash crop. Fortunately, some cultivars commonly cultivated have various degrees of resistance to one or more species and races of root-knot nematodes (Table 1, Gallaher and McSorley, 1993). This combination of nematode and nitrogen management could be especially useful in organic production systems where neither nematicides nor synthetic nitrogen fertilizers could be used.

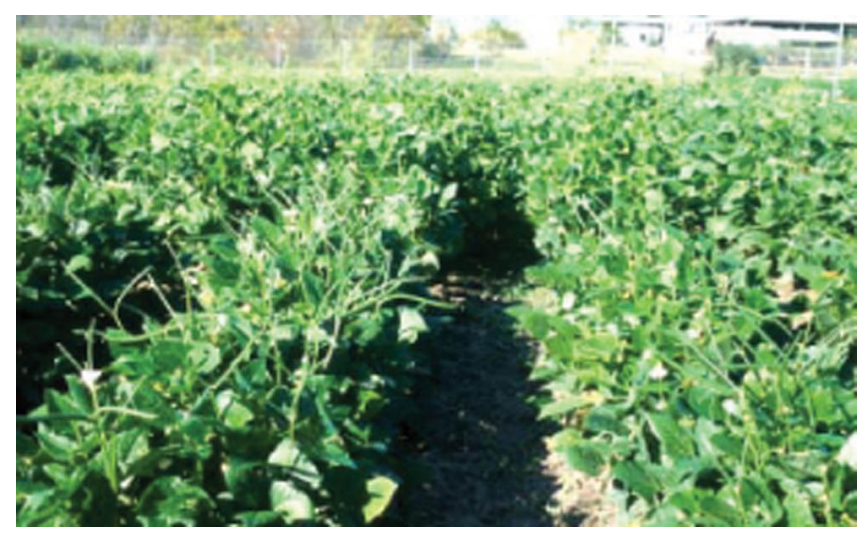

Figure 1. Cowpea planted as a cover crop. Credits: R. McSorley

1. This document is ENY-712, one of a series of the Department of Entomology and Nematology, Florida Cooperative Extension Service, Institute of Food and Agricultural Sciences, University of Florida. Date first printed: August 2004. Please visit the EDIS Web site at http://edis.ifas.ufl.edu.

2. K. -H. Wang and R. McSorley, Department of Entomology and Nematology, Cooperative Extension Service, Institute of Food and Agricultural Sciences, University of Florida, Gainesville, FL.

The Institute of Food and Agricultural Sciences (IFAS) is an Equal Opportunity Institution authorized to provide research, educational information and other services only to individuals and institutions that function with non-discrimination with respect to race, creed, color, religion, age, disability, sex, sexual orientation, marital status, national origin, political opinions or affiliations. U.S. Department of Agriculture, Cooperative Extension Service, University of Florida, IFAS, Florida A. \& M. University Cooperative Extension Program, and Boards of County Commissioners Cooperating. Larry Arrington, Dean 


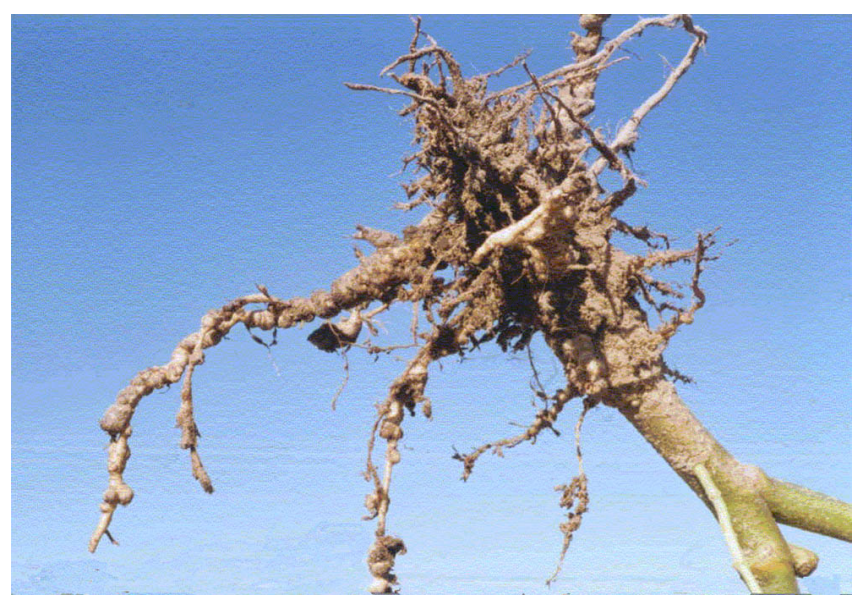

Figure 2. Root galling.

\section{Host Status of Cultivars of Cowpea to Plant-Parasitic Nematodes}

Host status of cowpea cultivars to various root-knot nematode species and races, and some other plant-parasitic nematodes are listed in Tables 1 and 2. The host status is categorized into 3 categories: poor, intermediate, and good hosts based on their susceptibility to the nematodes. Growers should avoid using good or intermediate hosts in their crop rotation if the specific nematode species or races are present in the field. Further information on the host status of cowpea cultivars to root-knot nematodes that might not be available on the market can be found in a publication by the International Meloidogyne Project (Sasser and Kirby, 1979) and a report from Arkansas (Kirkpatrick ad Morelock, 1987).

\section{How to Enhance Cowpea Effect}

Initial beneficial effects of cowpea rotation on root-knot nematode populations were lost once a susceptible vegetable crop like tomato or pepper was grown. Combining solarization with a nematode resistant vegetable cultivar may provide the organic vegetable grower with a viable means for root-knot nematode management (McSorley et al., 1999).

\section{Problems}

Responses of a root-knot nematode species to cowpea depend on the local nematode isolates. For example, $M$. javanica from Florida might not behave the same way as that from Hawaii. Therefore, we cannot be certain that a cultivar reported to be a poor

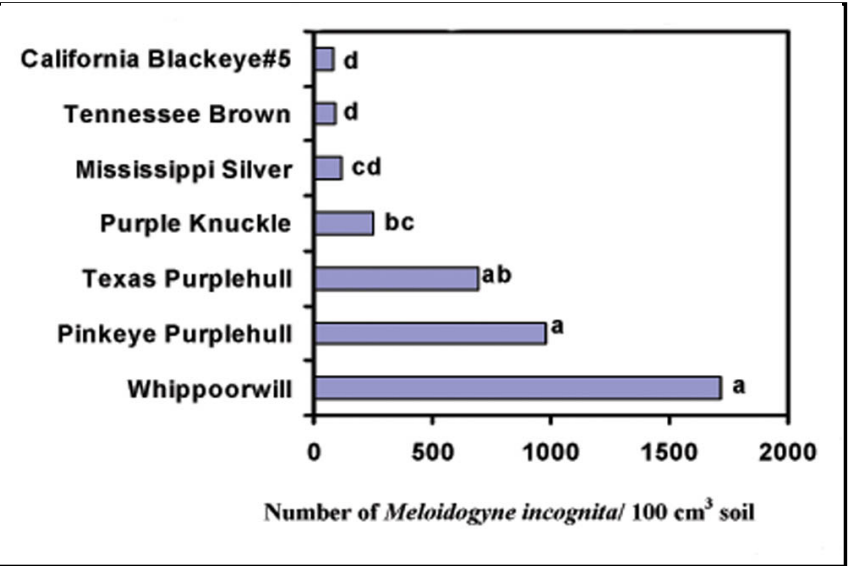

Figure 3. Population densities of the root-knot nematode, Meloidogyne incognita, following seven cowpea cultivars in Alachua County, Florida, 1991. Bars followed by the same letter are not different ( $P$ is less than or equal to 0.05 ), according to Duncan's multiple range test performed on log-transformed data (Gallaher and McSorley, 1993). Credits: Gallaher and McSorley, 1993

host for a particular root-knot nematode will behave in the same way in a field where the isolate has not been tested. For this reason, the resistance of a cowpea cultivar should be evaluated locally before it is widely planted.

In addition, behavior (virulence) of root-knot isolates within an area might also change over time. Studies at University of California, Riverside showed that a local population of the root-knot nematode, $M$. incognita, consisted of individuals varying in fitness. Although most of these root-knot isolates cannot reproduce on cowpea that contain the root-knot resistant gene, $R k$, some nematode isolates can overcome the resistant gene (Petrillo and Roberts, 2000). Continuous culture of root-knot resistant cowpea will favor the resistant isolates of nematodes. However, development of root-knot isolates that can overcome the resistant gene will be less likely to occur if resistant cowpea varieties are rotated with commercial crops that are susceptible to root-knot nematodes.

Another dilemma in selecting a suitable cowpea cultivar for nematode management arises when mixtures of different plant-parasitic nematode species occur in a field. Cowpea cultivars may be chosen for resistance against several nematodes if possible. Otherwise, it is critical to focus management options on the key nematode pest. 
It is important to note that cowpea is susceptible to some plant-parasitic nematodes, for example, the reniform nematode, Rotylenchulus reniformis (Robinson, et al., 1997). Fields infested with reniform nematode should not use cowpea for crop rotation. In addition, although 'Mississippi Silver' is a poor host to many root-knot species (Table 1) and the stubby-root nematode (Paratrichodorus minor), it is a good host to the sting nematode (Belonolaimus longicaudatus), another damaging plant-parasitic nematode (McSorley and Dickson, 1995).

\section{References}

Fassuliotis, G. 1976. Progress, problems and perspectives in breeding food crops for root-knot resistance, pp. 81-93, Proc. Res. Planning Conference on root-knot nematodes, Meloidogyne spp. January 12-16, North Carolina State University, Raleigh.

Gallaher, R. N., and R. McSorley. 1993. Population densities of Meloidogyne incognita and other nematodes following seven cultivars of cowpea. Nematropica 23: 21-26.

Kirkpatrick, T. L. and T. E. Morelock. 1987. Response of cowpea breeding lines and cultivars to Meloidogyne incognita and M. arenaria. Annals of Applied Nematology 1:46-49.

McSorley, R. 1999. Host suitability of potential cover crops for root-knot nematodes. Supplement to the Journal of Nematology 31: 619-623.

McSorley, R., and D. W. Dickson. 1995. Effect of tropical rotation crops on Meloidogyne incognita and other plant-parasitic nematodes. Supplement to the Journal of Nematology 27: 535-544.

McSorley, R., and R. N. Gallaher. 1991. Nematode population changes and forage yields of six corn and sorghum cultivars. Supplement to Journal of Nematology 23: 673-677.

McSorley, R., and R. N. Gallaher. 1992. Comparison of nematode population densities on six summer crops at seven sites in North Florida. Supplement to Journal of Nematology 24: 699-706.

McSorley, R., M. Ozores-Hampton, P. A. Stansly, and J. M. Conner. 1999. Nematode management, soil fertility, and yield in organic vegetable production. Nematropica 29: 205-213.

Petrillo, M. D., and P. A. Roberts. 2000. Influence of susceptible and resistant cowpea plants on life history traits of Meloidogyne incogita. Journal of Nematology 32:453 (Abstract).

Sasser, J. N., and M. F. Kirby. 1979. Crop cultivars resistant to root-knot nematodes, Meloidogyne species. Department of Plant Pathology, North Carolina State University, Raleigh, NC. 
Table 1. Cowpea cultivars that are poor host to root-knot nematodes.

\begin{tabular}{|c|c|c|c|}
\hline Cultivar & Target Nematode & Host Status & Reference \\
\hline Colossus & Meloidogyne incognita & Poor host & Fassuliotis, 1976 \\
\hline California Blackeye \#5 & M. incognita & Poor host & $\begin{array}{l}\text { McSorley and Gallaher, 1992; } \\
\text { Fassuliotis, } 1976\end{array}$ \\
\hline Iron Clay & M. incognita race 1 & Poor host & McSorley et al., 1999 \\
\hline Mississippi Purple & M. incognita & Poor host & Fassuliotis, 1976 \\
\hline Mississippi Silver & M. incognita race 1 and 3 & $\begin{array}{l}\text { Poor host/ } \\
\text { nonhost }\end{array}$ & $\begin{array}{l}\text { Gallaher and McSorley, 1993; } \\
\text { McSorley et al., 1999; } \\
\text { Kirkpatrick and Morelock, } \\
\text { 1987; Fassuliotis, } 1976\end{array}$ \\
\hline Tennessee Brown & M. incognita & Poor host & McSorley and Gallaher, 1992 \\
\hline Zippercream & M. incognita & Poor host & $\begin{array}{l}\text { McSorley and Dickson, 1995; } \\
\text { Fassuliotis, } 1976\end{array}$ \\
\hline
\end{tabular}

Table 2. Cowpea cultivars that are intermediate or good host to root-knot nematodes.

\begin{tabular}{|l|l|l|l||}
\hline \multicolumn{1}{|c|}{ Cultivar } & \multicolumn{1}{|c|}{ Target Nematode } & Host Status & \multicolumn{1}{c|}{ Reference } \\
\hline Purple Knuckle & M. incognita & $\begin{array}{c}\text { Intermediate } \\
\text { host }\end{array}$ & Gallaher and McSorley, 1993 \\
\hline Crimson & M. incognita race 3 & Good host & Kirkpatrick and Morelock, 1987 \\
\hline Elite & M. incognita race 3 & Good host & Kirkpatrick and Morelock, 1987 \\
\hline Elite & M. arenaria race 1 & Intermediate \\
host & Good host & Gallaher and McSorley, 1993 \\
\hline Whippoorwill & M. incognita & Good host & Gallaher and McSorley, 1993 \\
\hline Pinkeye Purplehull & M. incognita & Good host & Gallaher and McSorley, 1993 \\
\hline Texas Purplehull & M. incognita & \\
\hline \hline
\end{tabular}

